\title{
Constructivism Theory for Developing Business Technical Writing
}

Skills

An article derived from a Ph.D. dissertation entitled "A Suggested Proposed Program Based on Constructivism Theory for Developing Business Administration Students' Writing Skills"

Prepared by Noha Ismail Mohamed Eltorky

Assistant Lecturer in the Department of Business Administration, Canadian International College.

\section{Introduction}

In this article, the researcher is going to tackle the constructivism theory focusing on different constructivist strategies for developing business technical writing skills.

\section{Constructivism Theory}

The term constructivism has played a dominant role in educational literature for a number of decades. Constructivism is defined as "a process of constructing meaning; it is how people make sense of their experience" (Merriam, Caffarella, \& Baumgartner, 2007, p. 291). While educators in general agree on several essential aspects of constructivism, notably different interpretations, perspectives, and approaches exist regarding the details of constructivist learning and teaching. It has been at the forepart of academic debates among researchers and practitioners. Within the context of teaching, constructivism emphasizes non-transmitted methods of classroom instruction and has been contrasted in the literature with content-rich transmission model (e.g., Goldberg, 2002; Henson, 2001).

One initial principle of constructivism is that learners actively construct their knowledge, rather than simply absorbing ideas spoken to 
them by instructors (Larochelle, 2010). For example, Jean Piaget (1970) proposed that learners make sense in ways that they learn through the process of trying to make things happen and trying to manipulate their environment. Theories like these, which assert "people are not recorders of information, but builders of knowledge structures," have been grouped under the heading of constructivism (Pass, 2005). Thus, students are eventually responsible for their own learning within a learning atmosphere in which instructors value student thinking, initiate lessons that foster cooperative learning, provide opportunities for students to be exposed to interdisciplinary curriculum, structure learning around primary concepts, and facilitate authentic assessment of student understanding.

Gordon (2009) states that, "a constructivist approach to education is one in which learners actively create, interpret, and reorganize knowledge in individual ways" (p. 738). Moreover, constructivism is an educational learning theory that has the potential to create an educational experience where learning is more about understanding and applying concepts, constructing meaning, and critically thinking about ideas and not just accumulating random information, memorizing it, and repeating it. This theory is often described in contrast to a traditional transmission approach to learning where the learner is viewed as a passive container being filled with pre-determined knowledge, such as a formal lecture.

Browne (2009) affirms that the constructivism theory influences the teaching and learning of writing and has implications for students' selfassessment and for how students' writing is assessed by the instructor. Since a constructivist perspective stimulates the importance of the process of learning, that is, how students learn, assessing students' writing should 
focus on students' development as writers, rather than merely on the product of their writing. In this case, the assessment is integrated into classroom instruction and involves evaluation guidelines that empower instructors to recognize what the students know and what they can accomplish. Moreover, this permits the instructors to give feedback as a means of informing ongoing writing and to monitor the progress of their students.

Constructivist-learning environments are usually more informal; they promote close working relationships between students and instructors and depend on verbal activity by students. Instructors see many aspects of students' personalities and can easily assess each student's communication, argumentation, and problem-solving skills. Moreover, students are exposed to instructors' group leadership abilities (Jonassen, 2003).

Piaget's developmental theory acknowledges learning as an active process in which learners continually construct meaning through reading, listening, speaking, writing, exploration, and experience (Cox, 2005). Teaching should promote experiences that require students to become active, scholarly participators in the learning process (Gordon, 2009). However, there are challenges in translating constructivism as a theory of learning into practical instructional strategies that will enlighten this epistemology for instructor candidates (Richardson, 2003).

Brooks \& Brooks (2005) provide five principles of constructivist pedagogy: (a) posing problems of emerging relevance to learners; (b) structuring learning around "big ideas" or primary concepts; (c) seeking and valuing students' points of view; (d) adapting curriculum to address 
students' suppositions; and (e) assessing student learning in the context of teaching.

Phillips (2005) mention that the term constructivism has been used by such a large number of people and for a wide variety of purposes that there is almost no compromise as to its actual meaning. Constructivism is a theory of knowing and the nature of knowledge.

\section{Constructivism and Business Technical Writing}

A wide range of jobs demand employees to produce written documentation, visual text presentations, memoranda, technical reports, and electronic messages. The explosion of electronic and wireless communication in everyday life brings writing skills into play as never before. Recent reports by the National Commission on Writing (2004, 2005) show that the majority of both public and private employers say that writing proficiency has now become critical in the workplace and that it directly affects hiring and promotion decisions. The demand for writing proficiency is not limited to professional jobs but extends to clerical and support positions in government, construction, manufacturing, service industries, and elsewhere. In fact, about $30 \%$ of government and private sector employees require on-the-job training in basic writing skills.

Cox (2005) noted that the traditional approach of writing depends on teacher-controlled activities, and it focuses more on the product than the process. Browne (2009) mentions that in the traditional approach, instructors direct students to practise written language as a separate skill. This separate skill has been taught consecutively and without a writing context. Moreover, Morrow (2005) states that literacy learning involved linguistic and cognitive processes, thus promoting a move away from a 
product to a process approach to writing development. This was followed by a move towards viewing literacy as social and cultural practices, learned through everyday interactions in meaningful contexts (BarrattPugh, 2000). Consequently the focus was on the teaching of literacy in ways observing the literary events that are constructed according to the purpose, audience and context.

During the last three decades many approaches to teaching writing have been developed and implemented in schools, and these can be placed on a continuum ranging from traditional to constructivist-based approaches (Boscolo, 2008). One of the main themes in teaching writing influenced by constructivist perspectives on learning is that the writing activities and instruction should be based on what students recognize. Consequently, instruction should be built on what they already know (Browne, 2009).

Additionally, Browne (2009) mentions that students should be immersed in a print-rich environment, and wherever possible, should use real books and write original texts. Moreover, writing for a purpose and real audiences are central to a constructivist- based approach, which stresses the importance of authentic engagement in significant activities. Consequently, it is vital that students understand why they are writing and for whom they are writing.

Researchers find that another major influence of constructivist perspectives on learning to write is the importance of interaction. Interaction is seen as part of the process through which writing is viewed as a shared social practice that involves interaction between students and their peers and the instructor. Interactions within a social context involve

\section{5}


students in sharing, constructing and reconstructing their ideas (Barone et al., 2005).

Constructivist perspectives also influence the role taken by instructors in teaching writing. In constructivist oriented writing classes, instructors are viewed as facilitators of learning rather than as providers of knowledge and information (Cox, 2005). As a facilitator, the instructor provides a supportive environment that encourages students to see themselves as writers creating texts for varied, real audiences and for genuine purposes. Building on Vygotsky's (1978) concept of the zone of proximal development, instructors provide the scaffold for students' writing development, leading them eventually to take full control of their writing. There are five levels of support commonly identified as providing appropriate scaffolding for students learning to write. These are: modeled writing, shared writing, interactive writing, guided writing and independent writing (Vukelich \& Christie, 2009).

Furthermore, Grant and Knowles (2000) have argued that writing in university needs to be reframed. It may be much more constructive to position writing as a community-based, collaborative, even social act, dynamics that stand in sharp contrast to private, isolated, individualistic processes that often occur. The paradigm of language education shifted towards language as a means of communication, moving from studying language as a system towards enhancing the language in communicative situations (Sawyer \& Van de Ven, 2007). Technological advances, changing workplace demands, and cultural shifts make writing more important than ever, especially because the way learners write often 
predicts academic and job success, creates opportunities for participation, maintains relationships, and improves critical thinking.

Harris (2001) mentions that instructors should remember that writing is an individual effort and skill; therefore, the instructor's role is to share in the process by offering constructive criticism and correcting errors. Moreover, the instructor needs appropriate classroom explanation, so that students can understand what is expected of them. He sees that if writing is limited only to writing courses, then the students will have insufficient practical writing experience. Accordingly, writing needs to be stimulated, required, and assessed as part of all the other English courses students take.

In fact instructors cannot expect weak writers to improve simply by equipping them with the strategies of good writers. Instructors "need to explore ways of scaffolding students' learning and using knowledge of language to guide them towards a conscious understanding of target genres and the ways language creates meanings in context" (Hyland, 2003, p. 21). Feez (2002) mentions that one of the principles in the Sydney School's approach to genre pedagogy is that language learning occurs most effectively as part of an collaborative process of teaching and learning that involves modeling of the target text by the instructor, coproduction of an example of the target text by instructor and student (scaffolding), and lastly independent production of the target text by the learner.

Designing effective instructional environments in learning-to-write classes is to realize that writing and learning to write are interdependent capabilities (Rijlaarsdam \& Van den Bergh, 2004). A student, who performs a writing task in class, should have opportunities to learn from 
doing a writing task; writing and learning-to-write are different but connected processes (Rijlaarsdam \& Couzijn, 2000). Learning from completing a writing task is not provided by the doing itself. It should be stimulated via the instructional design. Consequently, well-designed writing lessons arouse the learner capability. This suggests that, at some instance, students are not writers, but learners. They observe, process, abstract, generalize and contextualize information from the learning environment into declarative, procedural and conditional knowledge; they become aware about what a good text in this context involves and/or how to produce such a text under the given circumstances.

To arouse students' learning-to-write competences, instruction should motivate them to observe and evaluate relevant processes: writing processes (strategies), text processing processes (reading), or communication processes between writers and readers.

Therefore, designers of writing classes should not focus on the role of the writer only. Designing writing lessons could be guided by the design rule that at least the learner role should be realized in the lessons. Input for learning can be writing, reading, or interaction between writer and reader. In some cases, the students act in several roles, in other cases, just in one. However, even if a student functions during the lesson just in one role, others will function in another way: there is always in some respect a complement.

Writing is a means to extend and deepen students' knowledge; it acts as a tool for learning subject matter (Shanahan, 2004). This role is called writing to learn. By using writing tasks to learn content offers students opportunities to develop their knowledge of vocabulary; to 
strengthen the planning, evaluating, and revising process; and to practice grammar, spelling, punctuation, modes of argumentation, and technical writing (Yore, 2003).

Although writing is often described as an isolated activity, it has several social dimensions, and effective instructors provide students opportunities to experience writing in interactive terms by encouraging students to work together at every stage of the writing process. Opportunities to work with peers in prewriting and drafting as well as revising aids students to develop a strong sense of audience and a more fully developed understanding of voice in writing. Monroe, B. W., \& Troia, G. A. (2006) state that struggling writers benefit from a combination of self-evaluation and peer evaluation; this benefits them to appropriate higher writing standards, improve self-regulation skills, and view writing as an individual and collaborative activity.

Writing instruction needs to aid students meet the challenges of writing efficiently for several purposes. It is stated that the growing demand for good writers requires more time and attention devoted to writing instruction and assessment to prepare all students for a changing world (Hillocks, G. 2008). Student writers enter the classroom with diverse needs and skills, including multiple languages, grammars, cultures, and extracurricular literacy practices; hence, different approaches and assessments are required to decrease the gaps between more advantaged and less advantaged writers. Attention to these gaps is important, as weak writing skills limit school, occupation, and advancement opportunities (National Committee on Writing, 2004). A research cannot identify one single approach to writing instruction that will be effective with every 
learner because of the diverse backgrounds and learning styles of students, who respond differently to various approaches. Furthermore, today's students will face varied writing demands in the future.

Brownstein (2001) mentions that according to the social constructivist approach, instructors have to adapt to the role of facilitators and not instructors. Where an instructor gives a informative lecture that covers the subject matter, a facilitator helps the learner to get to his or her own understanding of the content. This dramatic change of role suggests that a facilitator needs to display a different set of abilities than an instructor.

\section{Writing Assessment}

Bacha (2002) declares that testing writing is unquestionably hard. Assessing and evaluating writing in ELT has a long history with several procedures and scoring criteria being revised and adapted to meet the requirements of administrators, instructors and students. Recent approaches to academic writing instruction have demanded testing procedures that deal with both the process and the product of writing. When testing writing ability directly, there are some considerations to take into account:

1. The writing tasks should be properly representative of the population of tasks that should expect the students to be able to perform.

2. The tasks should produce samples of writing that represent the students' ability.

3. It is essential that the samples of writing can be scored reliably. 
To conclude, contemporary writing instruction recognizes that students need to write for a wide variety of real-life purposes. Competent writer can adapt to different contexts, formats, and purposes for writing. Most contexts of life call for writing skills, and each context makes overlapping but not equal demands. Furthermore, skilled writers can adapt their writing to its context. Moreover, writing is produced in different formats, such as sentences, lists, outlines, paragraphs, essays, letters, and memos, and competent writers can move among most of these formats. Furthermore, skilled writers are capable to move among purposes that range from writing only for themselves to communicating with an external audience. What is important is that excellent instruction in writing emphasizes correctness of forms and conventions and encourages in writers the command of a variety of forms, genres, styles, and tones, and the ability to adapt to different contexts and purposes. For writing skill, it should be taught in the context of real-world issues. Bridging the gap between reality and writing is the most difficult part. The context makes the writing meaningful; thus, examples should be presented in the context of real-world issues. Second, if the student has no fear of writing, wants to learn, and possesses a certain amount of writing experience, varied backgrounds need not lessen from the success of the course. Besides, they might essentially give a wider approach.

\section{Adopted Strategies to Develop BTW}

The coming section highlights four significant strategies emergent from the constructivism theory that will be utilized for developing the business technical writing skills. 


\section{Scaffolding Strategy}

Scaffolding is grounded in Vygotsky's socio-cultural theory. This theory is relied on the concept that human activities arise in cultural contexts and is mediated by language and other symbol system. The theory emphasizes the interdependence of social and individual processes in the construction of knowledge. The role of the instructor is sociocultural perspectives that go beyond providing a rich language environment to learners. The instructor uses the language as a cognitive tool to empower and facilitate the learners to develop thoughts and ideas in language. The thinking process shows development in learners, who become self-regulating and able to complete tasks as they reach their potential level of development (Huong, 2003).

According to Graham (2006), teaching writing strategies appears to be especially effective with low-achieving students. In its operational terms, instructors have to adopt the principles developed by constructivism theorists, i.e. introducing the technique of scaffolding as a way to help students construct their writing skill. Providing the students with a scaffold means giving them assistance, which gradually decreases, as they are getting stronger and finally become autonomous.

Feedback to students is crucial for effective pedagogy and plays a critical role in scaffolding students' achievement. Marzano, Pickering and Pollock (2001) found that putting objectives and providing efficient feedback is powerfully related to student achievement in their metaanalysis. Moreover, by being scaffolded or given a scaffold, students would be lifted from such a situation in the traditional way of teaching writing as writing without receiving enough feedback to help them develop 
their ideas in the process of writing. They receive feedback from their facilitator and their fellow classmates. Students use the feedback to check their writings, and so they do this rewrite-revise process before they edit, and finally submit their final writings. Therefore, it is the process of working on drafts until publication of writings that counts. This approach has to a certain degree encouraged students to write with confidence and to feel committed to their work; they are not worried about their writings being judged as right or wrong.

Galguera (2003) mentions that the educational scaffolds are "intentional, temporary, flexible structures built to match the learner's development" (p. 2). Scaffolding language is a well-known method to support EFL students cope with and gradually master BTW. Moreover, BTW definitely does not substitute for instructor competence with scaffolds, but it increases that competence. BTW focuses directly on real world, audience-oriented, nonfiction, non-narrative prose, so it provides scaffolding for more general literacy development. Furthermore, wise BTW practice is adjusted for university students and easily raises scaffolding.

Coit (2004) mentions that using peer feedback for correcting articles through a student-centered environment is a beneficial pedagogy to extend learners' academic writing practice. According to him, "Based on theories in collaborative learning and social cognitive development, peer review has assumed an important role in both first language and foreign language writing classrooms" (p. 902). When students are endorsed to take on the role of the editor for their peer's writing to do the correction process, they seem to be more confident and motivation-stimulated in their writing 
courses. There are many advantages of peer feedback that the students and instructors can identify.

\section{Mind Mapping}

Tony Buzan (2002) states that mind mapping is a graphic representation of ideas usually generated through a brainstorming session. It shows the ideas that are generated around a central theme and how they are linked. It is a tool mainly used for stimulating thought. He recognized that the education system primarily focused on the left and brain strength, which involves the use of language, logic, numbers, sequence, looks at detail, symbolic representation and judgmental characteristics. It is helpful for visual learners as they are illustrative tools that assist with managing thought, directing learning, and making connections (Stephens et al., 2007). Furthermore, it is a great way to introduce an overall topic, increase student involvement, and get thoughts down quickly. Mind mapping is a skill that cuts across ability levels and encompasses all subject matters (Goldberg, 2004).

Johnstone \& Otis (2006) state that mind maps have been implemented in problem-based learning. They mention that the reason why mind maps are considered to be beneficial for the PBL process is that they promotes the activation and elaboration of prior knowledge. By applying mind maps in PBL process, students have to visualize their previous knowledge in the form of a mind map, which helps them to separate what is already known form what needs to be investigated to better understand the problem and its fundamental mechanisms. By activating and elaborating on prior knowledge, mind mapping is likely to boost and facilitate the production of learning goals. Since mind mapping is expected 
to provoke a more extensive discussion and in-depth analysis of the concepts, propositions, mechanisms, and interrelations, instructors would expect to find both more and more adequate learning goals in groups working with mind maps.

\section{Inquiry-based Learning}

Inquiry-based teaching and learning strategies are strategies that strive to improve student achievement by engaging students in individual and group research of a topic, idea, or problem, within a process or model of discovery. Inquiry is an umbrella term that covers a number of other approaches to teaching and learning. It is an educational approach associated with problem-based learning in which the student learns through investigating issues or scenarios. Through this approach, students pose and answer questions individually and/or collaboratively to write conclusions regarding specific topics. Within the educational setting, inquiry-based learning has been beneficial in developing student inquiry, investigation, and collaboration skills, in turn, increasing overall understanding of the issue or situation (Hakverdi-Can \& Sonmez, 2012).

Brooks and Brooks (2005) state that constructivist instructors should encourage students' inquiry by asking thoughtful, open-ended questions and encouraging students to ask questions of each other, as complex, thoughtful questions, that have more than one response, challenge students to research into issues deeply and broadly and to form their own understandings of events.

According to Stripling (2003), "Inquiry learning follows a fairly standard process that involves starting with what the learner knows, asking intriguing questions about what is not known, investigating the answers, 
constructing new understandings, and communicating the share those understandings with others" (p. 3-4). As contrasted with more traditional forms of teaching and learning, inquiry highlights the process of learning to develop deep understanding in students and to acquire content knowledge and skills. Inquiry draws upon a constructivist learning theories where the learner builds understanding through the active development of conceptual mental frameworks (Jonassen, 2000).

\section{Writing Process and Inquiry-based Strategy}

Using the writing process is an inquiry-based strategy, in which students compose written work by engaging in such related activities as discussion, mind mapping, selecting a topic, planning, writing drafts, revising, redrafting, editing, and publishing a polished product. A researcher describes the writing process as demonstrating four stages: developing and organizing content, using knowledge of form and style, applying knowledge of conventions, and reflecting on skills and strategies.

Studies have emphasized that instructors should shift the present emphasis on learning by rote and passive application of learned facts to the use of effective critical thinking as the main tool of learning (Zoller, BenChaim, \& Ron, 2000). Furthermore, students should be encouraged to take an active role in creating understanding \& problem solving (Baker et al., 2008; Herman \& Knobloch, 2004; Parr \& Edwards, 2004). By IBL, students construct knowledge and understand through the instructor's encouragement to explore the world, discover knowledge, reflect, and think critically (Santrock, 2001). 


\section{Problem-based Learning}

The constructivist approach focuses on students' individual needs, interests and problem-solving skills. Rather than being a presenter of knowledge or a taskmaster, the instructor is an intellectual guide, a facilitator in the problem-solving process (B1kmaz, 2006). Students build the knowledge, combining it with all their other direct experiences of the real world. Learning is a meaningful process, in which the students have a responsibility of their own learning.

Jonassen (2004) noted that a problem is an unknown entity in some context in which the difference between a goal state and a current state is one of the significant attributes of the problem. Learners often confront what are called ill-structured problems, which are complex, ill-defined problems that learners encounter in everyday life. The ability to solve illstructured problems requires that problem solvers learn to think differently and flexibly enough where they focus on memorization and understanding. Moreover, Ge (2001) reported that the ability to problem-solve is consists of presenting the problem, developing a solution, making justifications for the proposed solution, and monitoring and evaluating the problem solving process and the solutions.

Furthermore, learners need to be able to think critically in order to solve a problem like professionals in their field and to link their knowledge to real-life situations (Park \& Jang, 2008). This calls for reform in learning environments because the traditional learning environment is not preparing learners for problem solving.

Problem-based learning consists of learning activities in which groups of students cooperate to solve particular problems. Problem 
solving involves a variety of different sub-skills that can be coordinated through goal-directed collaboration among students. Problem-based learning is used in classes that have small group work and large classrooms (Oliver, 2007).

\section{Research Results}

The rsearcher has arrived at the following results:

The current study proved to be effective as the experimental group's performance on the pre/post business technical writing skills test developed significantly in favor of the post business technical writing skills test a whole and in each kill of the test at (0.05) level. Furthermore, the experimental group attained progress in each skill of the test.

This indicates that the experimental group attained advanced competence in terms of the overall business technical writing skills as a whole, which means that the proposed program based on the constructivism theory was effective in developing second year Business Administration department students' business technical writing skills.

Moreover, results of the study regarding each of the business technical writing skills showed that there is a statistically significant differences between the mean scores of the experimental group students trained in the proposed program in the pre and post measurements on developing each writing skills: content, inquiry-based learning, problem solving, mechanics/sentence structure, formatting, organization, and style/word choice.

Additionally, results revealed variation in the significant differences among business technical writing skills as follows: content (30.33) with a strong effect size; inquiry-based learning (23.08) with a strong effect size;

\section{8}


problem solving (36.12) with a strong effect size; mechanics/sentence structure (2.34) with a weak effect size; formatting (17.90) with a strong effect size; organization (19.70) with a strong effect size; style/word choice (18.37) with a strong effect size; skills (45.99) with a strong effect size. This indicates that the students performed better in the business technical writing skills post test and this can be attributed to the nature of business technical writing skills and the constructivism theory.

\section{Findings of the Study}

Finding of the study can be summed up as follows:

First, the use of the proposed program based on the constructivism theory develops business technical writing skills for Business Administration department students.

Second, the use of constructivist activities increases students' motivation toward learning, as they tackle real life problems.

Third, providing students with a rubric according which they will be graded, helps students raise self-awareness. 


\section{Reference:}

Bacha, N. (2002). Developing Learners' Academic Writing Skills in Higher Education: A Study for Educational Reform. Language \&Education, 16(3), 161-177.

Barone, D.M., Mallette, M.H., \& Xu, S.H. (2005). Teaching early literacy. New York: The Guilford Press.

Barratt-Pugh, C. (2000). The socio-cultural context of literacy learning. In

C. Barratt- Pugh \& M. Rohl (Eds.), Literacy learning in the early years. Ballmoor, Buckingham: Open University Press.

B1kmaz, F. (2006). Yeni ilkogretim programları ve ogretmenler. [New elementary curricula and teachers]. Ankara University, Journal of Faculty of Educational Sciences, 39 (1), 97-116.

Boscolo, P. (2008). Writing in primary school. In C. Bazerman (Ed.), Handbook of research on writing: History, society, school, individual, text. New York: NY: Taylor \& Francis Group, LLC.

Brooks, J. G., \& Brooks, M. (2005). In search of understanding: The case for constructivist classrooms. Alexandria, VA: Association for Supervision and Curriculum Development.

Browne, A. (2009). Developing language and literacy 3-8 (3rd ed.). London: Sage.

Brownstein, B. (2001) 'Collaboration: the foundation of learning in the future', Education 122(2):240.

Buzan, T. (2002). How to Mind Map. Great Britain: Thorsons.

Coit C. (2004). Peer review in an online college writing course, Proceedings of the IEEE international conference on advanced learning technologies, 902-903. 
Cox, C. (2005). Teaching language arts, a student-and response-centered classroom (5th ed.). Needham Height, MA: Allyn and Bacon.

Feez, S. (2002). "Heritage and Innovation". In A. Johns (ed.) Genre in the Classroom. Mahwah: Lawrence Erlbaum Associates.

Galguera, Tomas. (2003). Scaffolding for English learners: what's a science teacher to do? FOSS Newsletter, (Spring) no. 21, 1-8.

Ge, X. (2001). Scaffolding students' problem-solving processes on an illstructured task using question prompts and peer interactions. Unpublished doctoral dissertation, Pennsylvania State University.

Goldberg, Cristine (2004). Brain friendly techniques: Mind mapping. School Library Media Activities Monthly, 21, 3, 22-24.

Goldberg, M. F. (2002). 15 School questions and discussion: from class size, standards, school supply to leadership and more. Lanham, MD: Scarecrow Press.

Gordon, M. (2009). The misuses and effective uses of constructivist teaching. Teachers and Teaching: Theory and Practice, 15(6), 737746. doi: 10.1080/13540600903357058

Graham, S. (2006). Strategy instruction and the teaching of writing: A meta-analysis. In C. MacArthur, S. Graham, \& J. Fitzgerald (Eds.), Handbook of writing research (pp. 187-207). New York: Guilford.

Grant, B. and S. Knowles (2000). Flights of imagination: academic women becoming writers. International Journal of Educational Development $5(1), 6-19$. 
Hakverdi-Can, M., \& Sonmez, D. (2012). Learning how to design a technology supported inquiry-based learning environment. Science Education International, 23(4), 338-352.

Harris, R. (2001). “ Some ideas for motivating students." Retrieved form: http://www.virtualsalt.com/motivate.htm.

Henson, K. T. (2001). Curriculum planning: Integrating multiculturalism, constructivism, and education reform. New York: McGraw-Hill.

Hillocks, G. (2008). Writing in secondary schools. In C. Bazerman (Ed.), Handbook of research on writing: History, society, school, individual, text (pp. 311-330). New Jersey: L. Erlbaum Associates.

Huong, L. (2003). The meditational role of language teaches in sociocultural theory. English Teaching Forum, 41(3), 31-35.

Hyland, K. (2003). "Genre-based pedagogies: a social response to process". Journal of Second Language Writing. 12:17-29. Pergamon.

Johnstone, A.H., \& Otis, K.H. (2006). Concept mapping in problem based learning: A cautionary tale. Chemistry Education Research and Practive, 7(2), 84-95. Doi: 10.1039/B5RP90017D

Jonassen, D. (2003). Designing Constructivist Learning Environments (CLEs). Retrieved January 28, 2012, from http://tiger.coe.missouri.edu/ jonassen/courses/CLE/

Jonassen, David H. (2000). Computers as mind tools for schools: Engaging critical thinking (2nd ed.). Upper Saddle River, NJ: Prentice Hall.

Larochelle, M. (2010). Constructivism and education. West Nyack, NY: Cambridge University Press.

Marzano, R., Pickering, D., \& Pollock, J. (2001). Classroom instruction that works: Research-based strategies for increasing student 
achievement. Virginia: Association for Supervision and Curriculum Development.

Merriam, S. B., Caffarella, R. S., \& Baumgartner, L. M. (2007). Learning in Adulthood: A Comprehensive Guide (3rd Ed.). San Francisco, CA: Jossey-Bass.

Monroe, B. W., \& Troia, G. A. (2006). Teaching writing strategies to middle school students with disabilities. Journal of Educational Research, 100(1), 21-33.

Morrow, L.M. (2005). Literacy development in the early years: Helping children read and write (5th ed.). Needham Heights, MA: Allyn and Bacon.

National Commission on Writing. (2004, September). Writing: A ticket to work... or a ticket out: A survey of business leaders. Retrieved July 31, 2012, from http://www.writingcommission.org/report/html.

Oliver, R. (2007). Exploring an inquiry-based learning approach with firstyear students in a large undergraduate class. Innovations in Education and Teaching International, 44, 3- 15.

Park, S. I., \& Jang, S. (2008). Analysis of peer-scaffolding patterns in four phases of problem-solving in web-based instruction. The SNU Journal of Education Research, 17, 1-30.

Pass, Susan (2005). Parallel paths to constructivism: Jean Piaget and Lev Vygotsky. Charlotte, NC: Information Age.

Phillips, R. A. (2005). Challenging the primacy of lectures: The dissonance between theory and practice in university teaching. Journal of University Teaching and Learning Practice, 2(1), 1. Retrieved from http://jutlp.uow.edu.au/2005_v02_i01/phillips003.html. 
Richardson, V. (2003). Constructivist pedagogy. Teachers College Record, 105(9), 1623-1640.

Rijlaarsdam, G. \& Van den Bergh, H. (2004). Effective learning and teaching of writing: Student involvement in the teaching of writing. In G. Rijlaarsdam, (Series Ed.), \& G. Rijlaarsdam, H. Van den Bergh, \& M. Couzijn (Vol. Eds.), Studies in writing. Vol. 14. Effective learning and teaching of writing, Part 1, Studies in learning to write (2nd ed., pp. 1-16). Dordrecht: Kluwer Academic Publishers.

Rijlaarsdam, G., \& Couzijn, M. (2000). Writing and learning-to-write. A double challenge. In R. Simons, J. Van der Linden \& T. Duffy (Eds.), New Learning (pp. 157-190). Dordrecht: Kluwer.

Sawyer, W., \& Van den Ven, P.-H. (2007). Starting points. Paradigms in Mother tongue Education. L1 - Educational Studies in Language and Literature, 7 (1), 5-20.

Shanahan, T. (2004). Overcoming the dominance of communication: Writing to think and to learn. In T. L. Jetton \& J. A. Dole (Eds.). Adolescent literacy research and practice (pp. 59-73). New York: Guilford.

Stephens, Pam and Hermus, Cindy (2007). Making art connections with graphic organizers. School Arts: The Art Education Magazine for Teachers, 106, 8, 55.

Stripling, Barbara (2003). Inquiry-Based Learning. In Curriculum Connections through the Library, edited by Barbara Stripling and Sandra Hughes-Hassell. Libraries Unlimited, 3-40. 
Vukelich, C., \& Christie, J. (2009). Building a foundation for preschool literacy : Effective instruction for children's reading and writing development. Newark, Del.: International Reading Association.

Vygotsky, L. (1978). Interaction between learning and development. In Gauvain \& Cole (Eds.) Readings on the Vygotsky, L.S. (1962) Thought and Language, Cambridge, MA: MIT Press.

Yore, L. D. (2003). Examining the literacy component of science literacy: 25 years of language arts and science research. International Journal of Science Education, 25, 689-725.

Zoller, U., Ben-Chaim, D., Ron, S., Pentimalli, R., Scolastica, S., Chiara, M., \& Borsese, A. (2000). The disposition toward critical thinking of high school and university science students: an interintra Israeli-Italian Study. 
Ain Shams Universität

Pädagogische Fakultät

Curricula und Methodik-Abteilung

\title{
Die Effizienz einiger Lernstrategien zur Entwicklung des Wortschatzes im DaF- Unterricht an der Vorbereitungsschule
}

Ein Forschungsplan für die Registrierung des Magistergrades

Methodik und Didaktik der deutschen Sprache

Vorgelegt von

Reham Badr El-Din Abd El- Aziz

Betreut von

Prof. Dr. Amal Abd Allah

Professorin an der

Curricula- und Methodik-

Abteilung

Pädagogische Fakultät

Ain Shams Universität.
Prof. Dr. Olaf Moritz

Gastprofessor an der Deutsch Abteilung

Philosophische Fakultät

Heluan Universität.

\author{
Dr. Duaa Abd El Karim \\ Assistanzprofessorin an der \\ Curricula- undMethodik-Abteilung \\ Pädagogische Fakultät \\ Heluan Universität.
}




\section{Problemstellung}

Es geht sich in dieser Forschung um die Effizienz der Lernstrategien bei der Entwicklung des Wortschatzerlernens bei den Lernern der Vorbereitungsschule.

\subsection{Einleitung}

Die Sprache gilt als ein der wichtigsten Phänomene der menschlichen Entwicklung, denn sie ist das Mittel des Menschen, um seine Gedanken und Gefühle aus zu drücken, mit den anderen um zu gehen und seine Bedürfnisse zu befriedigen. Das Fremdsprachenlernen bietet dem Menschen Möglichkeiten für ein besseres Leben, in dem es nicht nur das Individuum als auch die Gesellschaft nutzt. Das Erlernen von Fremdsprachen trägt zur Entwicklung der persönlichen und sozialen Identität des Individuums

bei (www.geocities.com/yemenitta/maqal26.htm 1 /10 / 2008).

Zur Zeit dominiert die zunehmende Globalisierung, die in allen Bereichen des menschlichen Lebens erscheint. Die Fremdsprachen spielen eine wichtige Rolle bei der Vermittlung dieser Entwicklungen. So erscheint die Wichtigkeit des Fremdsprachenunterrichts in den verschiedenen Lernstufen, um diese Entwicklungen zu halten (ww.dw-world.de/popups/ popup_print content 15/ 12/2008).

Wegen der pragmatischen und pädagogischen Perspektiven in den 70er Jahren des 20. Jahrhunderts entstand die kommunikative Methode beim Fremdsprachenlernen. Diese Methode förderte das sprachliche angemessene Handeln des Lerners in den verschiedenen Lebenssituationen. 
Dafür braucht der Lerner einen grossen Umfang vom Wortschatz (Roßa, 2013, 25 - 26).

Der Wortschatz ist von einer grossen Bedeutung in der Kommunikation, denn ein Gespräch zwischen den Menschen kann wegen Mängel an Wörtern aber nicht an grammatischen Regeln scheitern (Freudenstein, 1992, 544).

Der Wortschatz entwickelt sich ständig gemäss der menschlichen Gesellschaftsentwicklung. So kann das Wortschatzlernen nicht am Ende der Phasen des Sprachstudiums enden, sodern es ist ein lebenslanges Lernen. Das übergeordnete Ziel von dem Erlernen des Wortschatzes kann identifiziert werden, dass die Wörter gemäss der Situation und der Intention zur Verfügung stehen und auch, dass sie möglichst rasch zurückgerufen und richtig und vielfältig gebraucht werden (Heyd, 1991, 91; Bohn, 1999, $15)$.

Im Hinblick auf die Präsentation von Wörtern wird jedes Wort dem Lerner durch drei Komponenten vermittelt. Diese Komponenten sind die Bedeutung, die Orthographie und die Aussprache. Im Anfängerunterricht muss der Lerner zuerst mit dem Lautbild und der Bedeutung vertraut gemacht wird, bevor das Schriftbild präsentiert wird, weil die Präsentation vom Schriftbild zuerst zur falschen Aussprache führen kann (Heyd, 1991, 92).

Im Bezug auf das Einüben und das Erlernen des Wortschatzes kann man jede sprachliche Übung auch als eine Wortschatzübung betrachten. Es gibt zwei Aspekte der Wortschatzübungen. Einer davon ist kognitiv mental und der andere ist kommunikativ. Beim kognitiven Einüben soll der 
Wortschatz möglichst tief im Gedächtnis verankert sowie möglichst dicht und vieldimensional ins Assoziationsnetz des semantischen Gedächtnisses eingebunden werden. Beim kommunikativen Einüben soll der Bedeutungsumfang und die funktionale Verwendung der Wörter eingegrenzt werden, sodass sie in der mündlichen und schriftlichen Kommunikation möglichst angemessen verwendet werden (Eggert, 1994, 119 - 131).

Die kognitive Psychologie befasst sich mit dem Wortschatz. Die Ergebnisse der kognitiven Psychologie und der Linguistik führen zu wichtigen Grundsätzen für die Wortschatzarbeit im Unterricht (Scherfer, 1989, 6).

Durch Üben und Anwendung müssen Teile des bereits gelernten Wortschatzes aktiviert werden, so dass der neue Wortschatz möglichst vielfältig in die bestehende lexikalische Wissenstruktur eingebunden wird. Der Wortschatz soll in verschiedenen sprachlichen, thematischen und situativen Kontexten eingeführt und geübt werden, denn das wirkt das Wortschatzerlernen positiv aus (Scherfer, 1995, 230). Die Emotionen sind ein wichtiges Prinzip für die Organisation unseres Gedächtnisses und verändern die Assoziationen, die mit bestimmten Wörtern verbunden sind (www.daf.german.or.kr/arbeit/10-4wortschatz.doc Kim, Ok-seon (HUFS) 19/ 8/ 2008).

Da das Wörterlernen im Kopf der Lerner geschieht, soll man also fragen, ob und wie man diesen subjektiven Prozess noch besser unterstützen kann. Da erscheint die Rolle des autonomen Lernens(Rampillon/ Bimmel P, 2000, 78 - 79). Es bedeutet in diesem 
Zusammenhang die Fähigkeit der Lerner, sich die Wörter einer Fremdsprache weitgehend selbstständig an zu eignen. Das setzt die Erkenntnisse voraus, wie die Wörter am besten gelernt werden können. Das autonome Lernen reicht über den Unterricht und die Schulzeit hinaus. Als wesentliches Mittel dafür wird die Beherrschung von Lernstrategien und Lerntechniken angesehen. Das hat auch mit den gesammten Bedingungen des Unterrichts zu tun (Bohn, 1999, 94 - 97).

Die Strategie im allgemeinen gehört zu den zentralen Bestandteilen der kognitiven Lerntheorie und hängt eng mit dem konstruktivistischen Lernkonzept zusammen, das das Lernen als aktiven und dynamischen Prozess der individuellen Informationsverarbeitung betrachtet. Für dieses Lernen braucht man Strategien, um neue Informationen an schon vorhandenes Wissen an zu knüpfen (www.daf.german.or.kr/arbeit/104wortschatz.doc Kim, Ok-seon (HUFS) 19/ 8/ 2008).

Das Trainieren auf Lernstrategien beim Fremdsprachenlernen braucht Bewusstsein und Erklären, um die Lerner zu befähigen, die Fremdsprache weiterhin selbst $\mathrm{zu}$ lernen. Hier scheint die Rolle des Lehrers als Lernberater beim Vermitteln seinen Lernern Wissen über Lernstrategien und deren Gebrauch, beim Üben im Unterricht, wie Strategien zur Erreichung eines bestimmten Zieles führen und bei der Auswahl der besten Strategien für jedes Lernziel (Bimmel, 1993, 10).

Dazu profitieren Lernstrategien beim Fördern der Lerner zum Lernen, bei der Anregung ihrer Motivation zum Lernen, bei der Verantwortlichkeit für das eigene Lernen, dem Selbstvertrauen, und Erfahrungstransfer auf andere Aufgaben, andere Fächer und aufs Leben. Es gibt viele Strategien 
für das Wortschatzlernen wie zum Beispiel die Wörtererkennen und die Verwendung von der Visualisierung (Oxford, 1990, 10).

Da Wortschatz nicht als isolierte Fertigkeit betrachtet ist, wird er oft weniger fokussiert. Beim Wortschatzlernen konzentrieren sich die Lehrer auf das Wort selbst und nicht auf die Art und Weise des Lernens, damit dieses Wort besser beherrscht und tiefer im Gedächtnis verankert wird.

Als ein weiteres Hindernis beim Wortschatzlernen ist die begrenzten Evaluationsmöglichkeiten, dadurch die Lerner im Klassenzimmer beurteilt werden. Die gängige Praxis für Lehrer zu beurteilen, wie gut Lerner gelernt haben, ist das Diktat. In einem solchen Fall neigen die Lerner nur, die Form und die Aussprache der Wörter zu erinnern. In diesem Fall werden die Wörter kurzfristig erinnert. Ein weiterer Weg für die Bewertung des Wortschatzlernens ist die Frage (Ergänze die Lücken!). Diese Methode ist praktischer für die Speicherung der Wortbedeutungen.

In Ägypten ist die vorherschende Methode beim Wortschatzlernen das Vorlesen, Nachsprechen und das Auswendiglernen der Wörter. Das führt sicher zum Vergessen und verursacht keine sprachliche Kommunikation.

\subsection{Problemstellung}

Das Problem dieser Arbeit besteht in der Schwierigkeit beim Wortschatzerlernen.

Um dieses Problem zu behandeln, versucht die vorliegende Arbeit, auf die folgenden Fragen zu antworten: 
1. Welche Schwierigkeiten haben die Lerner der deutschen Sprache in den Experimentalschulen beim Wortschatzerlernen?

2. Durch welche Unterrichtseinheit wird der Wortschatz der Lerner der deutschen Sprache in den Experimentalschulen entwickelt?

3. Welche Effizienz hat die vorgeschlagene Unterrichtseinheit auf die Entwicklung des Wortschatzes bei den Lernern der Vorbereitungsschule?

\section{3. Zielsetzung und Begründung der Arbeit}

Die vorliegende Arbeit zielt den Einsatz von Vokabellernstrategien und die Lernerwahrnehmung der Nützlichkeit von diesen Lernstrategien ab, um einen Beitrag zur Entwicklung des Wortschatzerlernens bei den Lernern der Vorbereitungsschule zu leisten.

Die Arbeit soll die Auswirkungen des Trainings auf Vokabellernstrategien für die Lerner herausfinden, in dem die Lerner sich aktiv und verantwortlich am Lernen beteiligen.

Auf dieser Grundlage ist die Vermittlung von Lernstrategien im Unterricht notwendig, dadurch wird eine Atmosphäre vom Selbstlernen und Lernerautonomie erschöpft.

\section{4. Eingrenzung der Arbeit}

Die vorliegende Arbeit beschränkt sich auf:

1. Kairo Gouvernement, wo es viele Vorbereitungsschulen gibt, in denen die Lerner Deutsch als zweite Fremdsprache lernen. Die Kandidatin arbeitet als eine Deutschlehrerin bei einer Vorbereitungsschule. 
2. Die achte Klasse (die zweite Klasse der Vorbereitungsschule), da die Lerner eine ausreichende Menge vom Wortschatz haben, damit die Kandidatin die Unterrichtseinheit durchführen kann.

3. Einige Lernstrategien, die für die Lerner und den Wortschatz passen.

\section{5. Hypothesen der Arbeit}

1. Es sind abweichende Ergebnisse zwischen den Mittelwerten der Testgruppe im Vor- und Nachtest bezüglich des Wortschatzes zugunsten des Nachtests zu erwarten.

2. Es sind abweichende Ergebnisse im Nachtest zwischen den Mittelwerten der Test- und Kontrollgruppe bezüglich des Wortschatzes zugunsten der Testgruppe zu erwarten.

3. Es sind abweichende Ergebnisse zwischen den Mittelwerten der Testgruppe im Vor- und Nachtest bezüglich der Wortschatzlernstrategien: (Bilderverwendung, Re-kombinieren, Wortgruppenbilden, Kontexterfinden, Anders Äußern, Wörtererkennen) zugunsten des Nachtests zu erwarten.

4. Es sind abweichende Ergebnisse im Nachtest zwischen den Mittelwerten der Test- und Kontrollgruppe bezüglich der Wortschatzlernstrategien: (Bilderverwendung, Re-kombinieren, Wortgruppenbilden, Kontexterfinden, Anders Äußern, Wörtererkennen) zugunsten der Testgruppe zu erwarten.

\section{6. Terminologie der Arbeit}

\section{6. 1. Lernstrategien}

\section{3}


Der Begriff Lernstrategie ist keine klar definierte Bezeichnung (Mohr u.a., 2012, 4). Kriby bezeichnet die Lernfertigkeiten zum Beispiel als einfache Prozeduren bzw. Routinen, die bei der Ausführung von sehr spezifischen Aufgaben eingesetzt werden. Klauer definiert eine Lernstrategie als einen Plan für eine Handlungssequenz, die auf die Erreichung eines Lernziels gerichtet ist (Leopold, 2009, 11).

Einige Wissenschaftler wie Florio - Hansen (1997) versuchen, zwischen dem psycholinguistischen und dem didaktischen Gesichtspunkt über die Lernstrategien zu unterscheiden. Unter dem psycholinguistischen Aspekt umfassen die Lernstrategien die meist unbewusst verwendeten Vorgehensweisen von Fremdsprachenlernern wie Hypothesenbilden und Hypothesentesten sowie höherrangige Planungs-, Überprüfungs- und Bewertungsprozesse. Didaktisch werden Lernstrategien als mentale Handlungspläne bezeichnet, die die Lerner bewusst verwenden, um ein bestimmtes Ziel zu realisieren (Florio - Hansen, 1997, 147). Bei den mentalen Prozessen handelt es sich um kognitive Strategien z.B. die Verwendung einer Strategie zum Wortschatzerlernen und die metakognitiven Strategien wie die Planung einer Lernhandlung (Neuner Anfindsen, 2005, 29). Bimmel und Rampillon stimmen diesen didaktischen Gesichtspunkt zu, in dem sie die Lernstrategie als ein mentaler Plan definieren, um ein Lernziel selbstständig zu realisieren. Grundlegend dafür ist, dass der Plan dem Lerner bekannt ist (Rampillon/ Bimmel, 1996, 70).

Oxford definiert die Lernstrategie als bestimmte Tätigkeiten, die der Lerner macht, um das Lernen leichter, schneller, interessanter, mehr 
übertragbar auf neue Situationen und mehr selbstgerichtet zu machen (Oxford, 1990, 8).

Lernstrategien sind nach Friedrich und Mandl Handlungssequenzen zur Erreichung eines Lernziels und jene Verhaltensweisen und Gedanken, die die Lerner aktivieren, um ihre Motivation und den Prozess des Wissenserwerbs zu beeinflussen und zu steuern (Mandl/ Friedrich, 2006 106).

Lukesch definiert Lernstrategien als prozedurales Wissen zur Erreichung von Lernzielen (Lukesch, 2001, 225).

Klauer bezeichnet Lernstrategie als ein Plan für eine Handlungssequenz, die auf die Erreichung eines Lehrzieles gerichtet ist (Klauer, 1996, 138).

Nach Hasselhorn und Gold versteht man unter Lernstrategien Prozesse bzw. Aktivitäten, die auf ein Lern- oder Behaltensziel ausgerichtet sind und die über obligatorische Vorgänge bei der Bearbeitung einer Lernanforderung hinausgehen (Hasselhorn, Gold, 2006, 90).

Lernstrategie ist auch als eine Sequenz einzelner Lerntechniken definiert, mit der ein bestimmtes Ziel erreicht werden soll (Schiefele, 1996, 260).

\section{6. 2. Wortschatz}

Der Wortschatz schliesst die Gesamtheit der Wörter einer Sprache ein. Man verteilt die Wörter manchmal in Inhaltswörtern, die die Nomen, die 
Verben und die Attribute umfassen und als offene Wörter wegen ihrer ständigen Entwicklung bezeichnet. So entstehen immer neue Wörter und Bedeutungen. Die zweite Art ist die Strukturwörter (Funktionswörter) wie die pronomen, die Artikel, die Präpositionen und die Konjunktionen. Diese Art wird als geschlossene Wörter bezeichnet, denn ihre Zahl ist begrenzt. Eine weitere Klassifikation verteilt die Wörter in primären und sekundären Wörtern, die durch die Wortbildungsregeln von den primären Wörtern abgeleitet sind (Storch, 1999, 55).

Im Bereich des Fremdsprachenunterrichts ist die Unterscheidung zwischen aktiven Wörtern, die der Lerner produktiv verwenden kann, den passiven Wörtern, die der Lerner lernt aber beim Sprechen und Schreiben nicht verwendet und den potentiellen Wörtern. Diese potentielle Wörter kann der Lerner durch die Ableitungsregeln der Wörter verstehen. Dazu gibt es die sogenannten Internationalismen, die die selbe Bedeutung und selbe oder ähnliche Struktur in den verschiedenen Sprachen haben (Heyd, 1991, 91).

Von den zwei Hauptbegriffen kann einen anderen neuen Begriff entstehen u.z.

\section{6. 3. Wortschatzlernstrategien}

Cameron $(2005,92)$ definiert Wortschatzlernstrategien als Aktionen, die die Lerner führen, um die Wörter zu verstehen und zu erinnern. Diese Definition scheint aber umfassend und allgemein zu sein. Eine genauere Definition war von Catalan gegeben $(2003,56)$, wer Ideen von anderen Forschern wie Schmitt (1997), Oxford (1990) und Rubin (1987) zustimmt hat. Sie schlägt folgende Definition der Vokabellernstrategien: "Kenntnisse 
über den Mechanismus bzw., Prozesse und Strategien, die verwendet sind, um den Wortschatz zu lernen sowie Schritte und Massnahmen, die von den Lernern übernommen, um die Bedeutung unbekannter Wörter herauszufinden, die Wörter im Langzeitgedächtnis zu behalten, um sie gut $\mathrm{zu}$ erinnern und, um sie in mündlicher oder schriftlicher Form zu verwenden". Nation (2001, 201), behauptet, dass es nicht leicht ist, um zu einer Definition zu gelangen. Er schafft eine Liste von den Merkmalen einer Wortschatzlernstrategie, die der Sprachenlerner verwendet. Eine Strategie bei ihm muss;

1. Wahl beinhalten, das heisst, es gibt mehrere Strategien zur Auswahl. 2. komplex sein, das heisst, es sind mehrere Schritte zu lernen. 3. Kenntnisse erfordern und sie von der Ausbildung profitieren. 4. die Effizienz der Vokabellernen und Vokabelverwendung steigern.

Ein gemeinsames Merkmal unter den oben genannten Definitionen ist, dass Wortschatzlernstrategien Aktionen sind, die die Lerner führen, um das Beihilfen beim Lernprozess von neuen Wörtern sicherzustellen. Die Rolle der Lerner dabei ist eine eher aktiv zu erwarten.

\section{7. Methodisches Vorgehen}

1. Bestimmung der Schwierigkeiten, die den Lernern der Vorbereitungsschule beim Wortschatzlernen begegnen.

Das wird durch Folgendes geleistet:

- Sichtung der Fachliteratur im Fach Wortschatz.

- Durchführung eines Interviews mit den Lernern, um die Schwierigkeiten, die ihnen begegnen, zu bestimmen. 
- Erstellung der Schwierigkeiten in einer Liste.

- Bestimmung des Wortschatzes im zweiten Schuljahr der Vorbereitungsschule.

- Bestimmung der passenden Lernstrategien für die Wortschatzentwicklung bei den Lernern der Vorbereitungsschule.

2. Erstellen der Unterrichtseinheit im Lichte der Lernstrategien zur Entwicklung des Wortschatzes.

Das wird durch Folgendes geleistet:

- Sichtung der Fachliteratur zu den Themen Wortschatz, Strategien, autonomes Lernen, Lerntypen, Lerntechniken und die Relation zwischen dem Wortschatz und den Lernstrategien.

- Bestimmung der Schritte und Ziele der vorgeschlagenen Unterrichtseinheit.

- Bestimmung der Unterrichtsmethoden, Unterrichtsmittel und die Lernaktivitäten, die zum Erfolg der Verwendung von Lernstrategien beitragen.

- Bestimmung der Rollen des Lehrers sowie des Lerners.

- Bestimmung der Evaluationsverfahren.

- Beurteilung der vorgeschlagenen Unterrichtseinheit durch Spezialisten des Faches Deutsch als Fremdsprache.

3. Realisierung der Unterrichtseinheit.

Das wird durch Folgendes geleistet:

- Wahl der Testgruppe. 
- Verteilen der Gruppe in zwei Gruppen. Eine davon ist Experimentalgruppe und die andere ist Kontrollgruppe.

- Erstellung eines Vortestes und seine Durchführung in den beiden Gruppen, um das Niveau jeder Gruppe zu bestimmen.

- Umsetzung eines Nachtestes in den beiden Gruppen, um die Wirkung der vorgeschlagenen Unterrichtseinheit auf die Entwicklung des Wortschatzes zu erforschen.

- Umsetzung der vorgeschlagenen Unterrichtseinheit in der Experimentalgruppe.

- Statestische Auswertung der Ergebnisse.

- Schlussfolgerungen und Konsequenzen für Deutsch als Fremdsprache.

\section{Literaturverzeichnis}

1. Bimmel, Peter (1993): Aktuelles Fachlexikon. In: Fremdsprache Deutsch 1 / 1993, Lernstrategien' (51).

2. Bohn, Reiner( 1999): Probleme der Wortschatzarbeit. Fernstudieneinheit 22, Langenscheidt, München.

3. Cameron, Lynne (2005): Teaching Languages to Young Learners, Cambridge University Press, United Kingdom.

4. Catalan, J.M.R. (2003): Sex differences in L2 vocabulary learning strategies, International Journal of Applied Linguistics, 13 (1) (2003), pp.54- 77.

5. Eggert, Sylvia (1994): Das Gedächtnis überlisten! - Gedanken zur Systematisierung und Differenzierung im DaF-Unterricht. In: Wolff, 
Armin/Gügold, Barbara (Hrsg.): Deutsch als Fremdsprache ohne Mauern. $119-131$.

6. Florio-Hansen, I. de (1997): "Learning Awareness" als Teil von, Language Awareness', Zur Sprachbewußtheit von Lehramtstudierenden“. In: Fremdsprachen Lehren und Lernen, Zur Theorie und Praxis des Sprachunterrichts an Hochschulen, 1997, (144 - 155).

7. Freudenstein, Reinhold (1992): Wählem Sie Kanal 93! Unterrichtsmaterialien für das 21. Jahrhundert. In: Info DaF 1-5, (543 $550)$.

8. Hasselhorn, Marcus; Gold, Andreas (2006): Pädagogische Psychologie: Erfolgreiches Lernen und Lehren, Kohlhammer, W. Kohlhammer Verlag, Stuttgart.

9. Heyd, Getraude (1991): Deutschlehren: Grundwissen für den Unterricht in Deutsch als Fremdsprache, Diesterweg, Frankfurt am Main.

10. Klauer, K. J. (1996): Über das Lehren des Lernens. In C. Spiel, U. Kastner-Koller \& P. Deimann (Hrsg.), Motivation und Lernen aus der Perspektive lebenslanger Entwicklung, (135-149), Waxmann, München.

11. Leopold, Claudia (2009): Lernstrategien und Textverstehen: Spontaner Einsatz und Förderung von Lernstrategien, Waxmann Verlag, Göttingen.

12. Lukesch, Helmut (2001): Psychologie des Lernens und Lehrens, Roderer, Regensburg. 


\section{Mandl, Heinz; Friedrich, Helmut Felix (2006): Handbuch} Lernstrategien, Hogrefe Verlag, Göttingen.

14. Mohr, Imke-Carolin et al. (2012): Fremdsprache Deutsch: Zeitschrift für die Praxis des Deutschunterrichts/ Heft 46/2012 - Lernstrategien, Hueber Verlag, München.

15. Nation, I. S. P. (2001): Learning Vocabulary in Another Language, Cambridge University Press, Cambridge.

16. Neuner-Anfindsen, S. (2005): Fremdsprachenlernen und Lernerautonomie. Sprachlernbewusstsein, Lernprozessorganisation und Lernstrategien zum Wortschatzlernen in Deutsch als Fremdsprache, Schneider Hohengehren, Baltmannsweiler.

17. Oxford, Rebecea (1990): Language Learning Strategies. What every Teacher should know, Heinle \& Heinle Publishers, Boston.

18. Rampillon, Ute; Bimmel, Peter (1996): Lernerautonomie und Lernstrategien. Fernstudieneinheit (Erprobungsfassung), Goethe-Institut, München.

19. Rampillon, Ute; Bimmel, Peter (2000): Lernerautonomie und Lernstrategien, Langenscheidt, Berlin u.a..

20. Roßa, Anne-Elisabeth (2013): Zum Verhältnis von Allgemeiner Didaktik und Fachdidaktik in der Lehrerbildung: Einschätzungen von Lehramtsstudierenden zur Fähigkeitsentwicklung in universitären Praxisphasen, Julius Klinkhardt, Kempten. 
21. Rubin, Joan (1987): Learner Strategies: theoretical Assumptions, Research History and Typology. In: Wenden, Anita / Rubin, Joan 1987: Learner Strategies in language Learning, Prentice Hall International, UK..

22. Scherfer, Peter (1989): "Vokabellernen". Der fremdsprachliche Unterricht 23, Heft 98, (4-9).

23. Scherfer, Peter (1995): " $\mathrm{Zu}$ einigen Aspekten der Erforschung des mentalen Lexikons von Fremdsprachenlernern“. In Bausch, Karl-Richard; Christ, Herbert; Königs, Frank G.; Krumm, Hans-Jürgen (Hrg.): Erwerb und Vermittlung von Wortschatz im Fremdsprachenunterricht. Arbeitspapier der 15. Frühjahrkonferenz zur Erforschung des Fremdsprachenunterrichts, Narr, Tübingen.

24. Schiefele, Ulrich; Pekrun, Reinhard (1996): Psychologische Modelle des fremdgesteuerten und selbstgesteuerten Lernens. In: Weinert, Franz E. (Hrsg.): Psychologie des Lernens und der Instruktion Band 2, Enzyklopädie der Psychologie, Serie I Pädagogische Psychologie, (249278), Hogrefe Verlag für Psychologie, Göttingen / Bern u.a..

25. Schmitt, N. (1997): Vocabulary learning strategies. In N. Schmitt \& M. McCarthy (Hrsg.). Vocabulary: Description, Acquisition and Pedagogy (199-227), Cambridge University Press, Cambridge.

26. Stroch, Günther (2008): Deutsch als Fremdsprache: Eine Didaktik; Theoretische Grundlagen und praktische Unterrichtsgestaltung, Fink, München.

\section{Internet-Websiten}


1. http://www.daf.german.or.kr/arbeit/10-4wortschatz.doc Kim, Ok-seon (HUFS) 19/ 8/ 2008.

2. http://www.dw-world.de/popups/ popup_print content 15/12/2008.

3. http://www.geocities.com/yemenitta/maqal26.htm 1./10/2008. 